\title{
Identification of 5,5'-Dithio-bis-2-nitrobenzoic Acid (DTNB) and Alkali Light Chains of Piscine Myosin
}

\author{
Shugo Watabe, * Yoshihiro OchiaI, ${ }^{*}$ and Kanehisa Hashimoto* \\ (Received October 24, 1981)
}

\begin{abstract}
Myosins were prepared from the ordinary muscles of 14 species of fish, and analyzed for light chain subunits by SDS-gel electrophoresis. DTNB light chain and two alkali light chains $A_{1}$ and $A_{2}$, in the order of increasing mobility, were dissociated from the myosin of each fish. Molecular weights of the myosin subunits were determined to be in the ranges 17,500-21,000 for DTNB light chains, 25,000-30,000 for $A_{1}$, and 13,500-22,500 for $A_{2}$ light chains, respectively.

In each scombroid fish tested, the molecular weight of $A_{2}$ was clearly larger than that of DTNB light chain; the opposite result was found in several other fishes including carp and pufferfish. In the group of fishes such as sardine and horse mackerel, both light chains showed the same molecular weight. These results suggested that there is some correlation between the molecular weight of $\mathrm{A}_{2}$ and the locomotory activity of fish.

Quantitative analysis showed that piscine myosins contained approximately two moles each of DTNB and of alkali light chains per mole. However, the ratios of $A_{1} / A_{2}$ differed widely, from 0.1 (grunt) to 2.6 (requiem shark).
\end{abstract}

Myosin, a fibrous protein whose molecular weight is approximately 480,000 is composed of four light chains of molecular weight of about 20,000 and two heavy chains of that of about $200,000 .^{1-5)}$ The myosins from rabbit fast muscle and other sources have three kinds of light chain designated $L_{1}, L C_{2}$, and $L_{3}$ in the order of decreasing molecular weight. ${ }^{b-10}$ One of them can easily be dissociated when myosin is treated with a sulfhydryl reagent, 5, 5'-dithio-bis-2-nitrobenzoic acid (DTNB), and is referred to as DTNB light chain."4,11) The DTNB light chains from various sources have so far been demonstrated to correspond to $\mathrm{LC}_{2}{ }^{2,4,7-8,11)}$ The dissociation of DTNB light chain does not significantly change the ATPase activity of myosin. ${ }^{2,12}$ Two other light chains $\mathbf{L C}_{1}$ and $\mathrm{LC}_{3}$ can be separated from myosin by alkaline treatments, and are called alkali light chains $A_{1}$ and $A_{2}$, respectively. ${ }^{5,13,14)}$ As their amino acid sequences indicate, these two chains are encoded by homologous genes, ${ }^{15)}$ and are essential to myosin ATPase. ${ }^{\text {) }}$

The piscine myosin is very similar to the mammalian myosin in physicochemical properties such as amino acid profile, sedimentation coefficient, and intrinsic viscosity, suggesting that both myosins have essentially the same molecular structure. ${ }^{18-24)}$
However, the stability of fish myosin generally is much lower than that of mammalian myosin when measured using ATPase activity or aggregation rate as a parameter. ${ }^{10,24-28)}$ In addition, the stability of fish myosin is remarkably speciesspecific: e.g., tilapia and carp myosins are about 30 and 10 times, respectively, more stable than mackerel myosin at $30^{\circ} \mathrm{C}$, when examined on ATPase activity. ${ }^{24,27)}$ In this connection, it has been demonstrated by sodium dodecyl sulfate (SDS)-gel electrophoresis that the ordinary muscle myosins from various fishes contain three types of light chains, and that the electrophoretic patterns are mostly species-specific. ${ }^{29-92}$ )

These findings led us to suppose that myosin light chains of fish are closely related to the stability and physiological functions of the myosin. Studies along those lines are, however, quite poor: FoCANT et $a l^{33-35)}$ isolated three types of light chains from the myosin of carp, trout, and pike, and showed that the molecular weight of DTNB light chain is between those of both other chains as in the mammalian myosin. No other papers are avialable.

We attempted to purify myosins from the ordinary muscles of 14 species of fish, mostly marine, and to analyze their light chain patterns. Results showed that $\mathrm{A}_{2}$ light chain has the molecular

* Lab. of Marine Biochem., Fac. of Agric., The Univ. of Tokyo, Bunkyo, Tokyo 113 (渡部終五・落合芳博・ 橾本周久: 東京大学農学部水産化学研究室). 
weight larger than or equal to DTNB light chain, in migratory fishes such as bigeye tuna and skipjack.

\section{Materials and Methods}

\section{Materials}

Thirteen marine and one fresh water fish were used: Mackerel Pneumatophorus japonicus, skipjack Katsuwonus pelamis, bigeye tuna Thunnus obesus, round herring Etrumeus micropus, sardine Sardinops melanosticta, horse mackerel Trachurus japonicus, bigeye scad Thachurops crumenophthalmus, threadfish Alectis cilialis, cutlassfish Trichiurus lepturus, pufferfish Fugu pardale, grunt Parapristipoma trilineatum, filefish Navodom modestus, carp Cyprinus carpio, and requiem shark Triakis scyllia. Rabbit was also used for comparison. With the sardine, horse mackerel, requiem shark and carp, live specimens were used. Other fishes were frozen with dry ice immediately after capture and kept at $-40^{\circ} \mathrm{C}$ until used. Piscine ordinary and rabbit fast muscles were carefully excised from the dorsal part, avoiding any dark or slow muscle.

\section{Preparation of Myosin Light Chains}

The following procedures were performed at $0-4^{\circ} \mathrm{C}$ unless otherwise stated. Myosins were prepared by the method of STAFFord et al., ${ }^{36)}$ except that the ammonium sulfate fractionation was carried out between $40-50 \%$ instead of $40-70 \%$ saturation. The whole, DTNB and alkali light chains were prepared from each myosin as described below.

Whole light chains: To a portion of the myosin solution thus obtained was added an equal volume of $0.05 \mathrm{M}$ Tris- $\mathrm{HCl}(\mathrm{pH} 8.0$ ) containing $8 \mathrm{M}$ urea, $0.01 \mathrm{~m}$ EDTA, and $0.01 \mathrm{~m}$ dithiothreitol according to LowEY and HoLt. ${ }^{37}$ The mixture was stirred at room temperature for $30 \mathrm{~min}$, added 10 volumes of ice-cold water, and centrifuged at $5,000 \times \mathbf{g}$ for $15 \mathrm{~min}$. The resulting supernatant was used as whole light chain fraction.

DTNB light chain: To another portion of the myosin solution was added an equal volume of $0.01 \mathrm{M}$ Tris- $\mathrm{HCl}(\mathrm{pH} 8.5)$ containing $0.5 \mathrm{M}$ $\mathrm{KCl}, 0.02 \mathrm{M}$ DTNB, and $0.02 \mathrm{M}$ EDTA according to FoCANT and Huriaux. ${ }^{33)}$ The mixture was allowed to stand at $0^{\circ} \mathrm{C}$ for $10 \mathrm{~min}$, added 10 volumes of ice-cold water, and centrifuged. The supernatant obtained was used as DTNB light chain fraction.

Alkali light chains: The precipitate obtained at the last step in DTNB light chain separation was used for preparing alkali light chains by the method of GAETJENS et $a l^{5}{ }^{5}$ The precipitate was allowed to stand at $0^{\circ} \mathrm{C}$ for $10 \mathrm{~min}$ in $0.1 \mathrm{M}$ glycine- $\mathrm{KOH}(\mathrm{pH} 11.1)$ containing $2 \mathrm{M} \mathrm{LiCl}$ and $1 \mathrm{~mm}$ dithiothreitol. To the solution was added a neutralized $2.5 \mathrm{~m}$ potassium citrate to a final concentration of $0.8 \mathrm{M}$. The mixture was left for another $10 \mathrm{~min}$, and centrifuged to obtain alkali light chain fraction.

Analytical Methods

SDS-gel electrophoresis was performed according to WeBER and OSBORN, ${ }^{\text {s8) }}$ using $10 \%$ polyacrylamide gels containing $0.1 \%$ SDS. Slab-gel electrophoresis was carried out by the method of PerRIE and PERRY, ${ }^{30)}$ using $10 \%$ polyacrylamide gels containing $8 \mathrm{~m}$ urea. After electrophoresis, gels were stained with Coomassie brilliant blue.

Molecular weights of the light chains were measured using bovine serum albumin, ovalbumin, chymotrypsinogen A, and cytochrome $c$ (Schwartz) Mann) as standard protein markers.

The myosins prepared as above were electrophoresed to estimate molar ratios of DTNB and both alkali light chains. After the run, gels were stained and scanned at $550 \mathrm{~nm}$ with a Gelman ACD-18 densitometer. Molar ratios of respective light chains were calculated using their molecular weights, on the assumptions that their staining intensities per unit weight match each other, and that each myosin contains four light chains.

\section{Results and Discussion}

The piscine myosins used contained some actin, tropomyosin, and troponin, as seen in SDS-gel electropherograms of their whole light chain fraction (pattern 2 in Fig. 1). However, simultaneous analyses of the DTNB and alkali light chain fractions (patterns 1 and 3 in Fig. 1) made it possible to differentiate respective light chains. The results obtained are schematically shown in Fig. 2. Three light chains were observed in most piscine myosins, but only two in those of round herring, sardine, bigeye scad, and horse mackerel. In these four fishes, DTNB and $A_{2}$ light chains were expected to possess practically the same mobility under the electrophoretic conditions adopted. When the whole light chain fraction of horse mackerel was electrophoresed in the presence of $8 \mathrm{M}$ urea, three bands appeared, one of which was DTNB light chain with an intermediate mobility (Fig. 3). This was also 

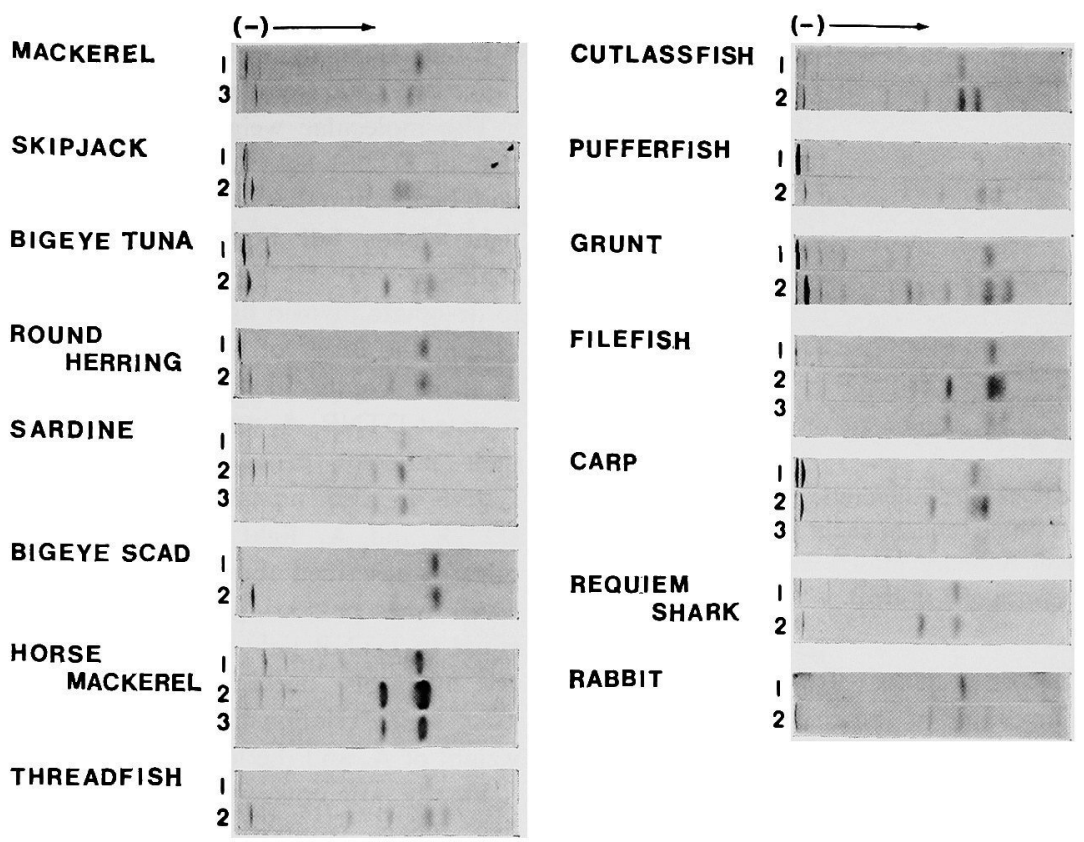

Fig. 1. SDS-gel electrophoretic patterns of DTNB (1), whole (2), and alkali (3) light chain fractions from piscine ordinary muscle myosins (10\% gels).

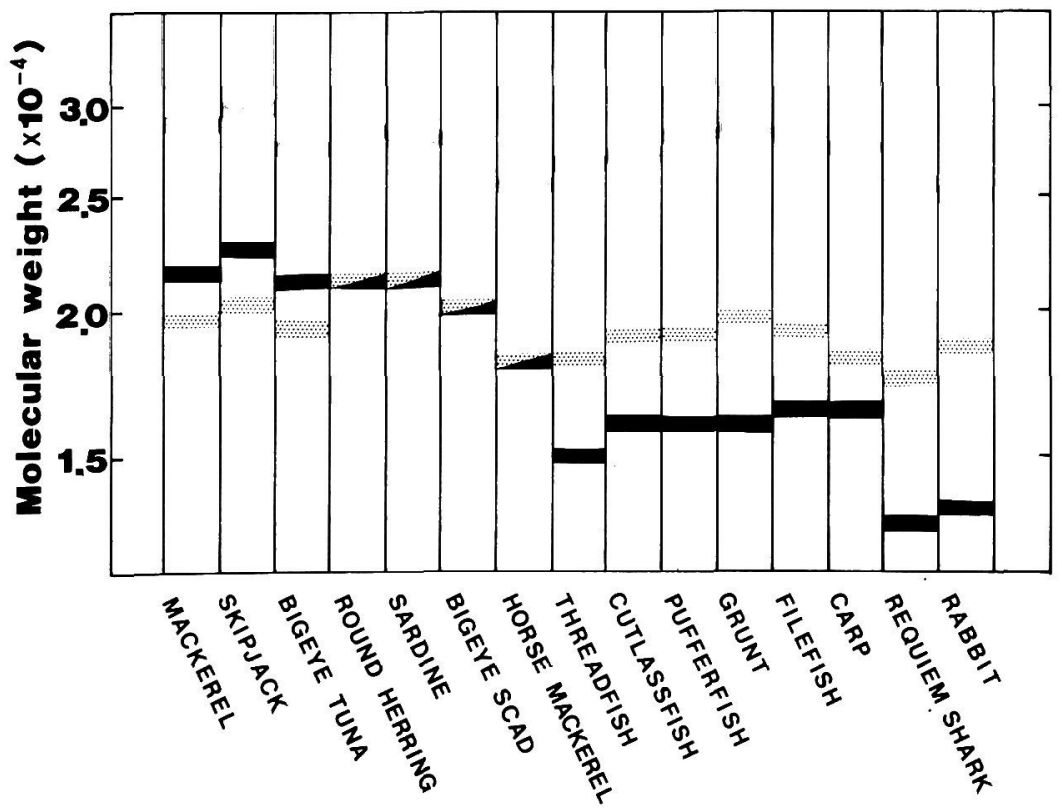

Fig. 2. Schematic diagram of SDS-gel electrophoretic patterns of light chains from piscine ordinary muscle myosins. Grey, black, and dotted bands represent $A_{1}, A_{2}$, and DTNB light chains, respectively. 


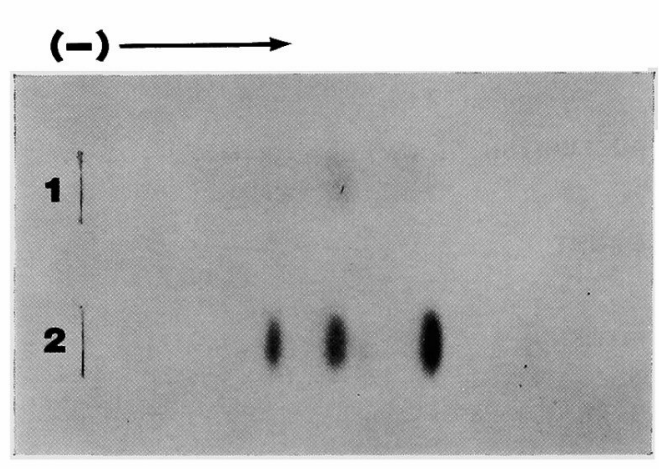

Fig. 3. Slab-gel electrophoretic patterns of DTNB (1) and whole (2) light chain fractions from horse mackerel ordinary muscle myosin $(10 \%$ gel in the presence of $8 \mathrm{~m}$ urea).

true for three other fishes. It follows that $\mathrm{A}_{2}$ and DTNB light chains of these four fishes have the same molecular weight, though both light chains differ from each other in net charge.

The molecular weights of the light chains determined by SDS-gel electrophoresis are shown in Table 1. The molecular weights of DTNB and $A_{1}$ light chains fall in fairly narrow ranges of
$17,500-21,000$ and $25,000-30,000$, respectively. Another alkali light chain $\mathrm{A}_{2}$, elicited the widest range of 13,500 (requiem shark)-22,500 (skipjack).

The molecular weight of $\mathbf{A}_{2}$ was larger than that of DTNB light chain in mackerel, skipjack, and bigeye tuna, whereas all the known DTNB light chians fall between the two alkali light chains. $^{2,4,7-8,11,33-35)}$ Therefore, it is not suitable to designate myosin light chains as $\mathrm{LC}_{1}, \mathrm{LC}_{2}$, and $\mathrm{LC}_{3}$ in the order of decreasing molecular weight in these scombroid fishes. They should be designated DTNB, $A_{1}$ and $A_{2}$ light chains, based on their inherent properties. The LC-designation system is also unsuitable to the fishes whose DTNB and $A_{2}$ light chains overlap with each other as described above.

All fishes possessing $\mathbf{A}_{2}$ which is larger than or equal to DTNB light chain in molecular weight, are migratory ones, indicating that there may exist some relationship between the molecular weight of $\mathrm{A}_{2}$ and the locomotory activity of fish.

Finally attempts were made to examine the light chain composition of the myosins. As summarized in Table 2, the piscine myosins contained about two moles of DTNB light chain per mole as has already been reported for rabbit fast

Table 1. Molecular weights of light chains from piscine ordinary muscle myosins, as determined by SDS-gel electrophoresis

\begin{tabular}{|c|c|c|c|c|c|}
\hline & $\begin{array}{l}\text { Light } \\
\text { chains }\end{array}$ & $\begin{array}{c}\text { Molecular } \\
\text { weight }\end{array}$ & & $\begin{array}{l}\text { Light } \\
\text { chains }\end{array}$ & $\begin{array}{l}\text { Molecular } \\
\text { weight }\end{array}$ \\
\hline Mackerel & $\begin{array}{l}A_{1} \\
A_{2} \\
\text { DTNB }\end{array}$ & $\begin{array}{l}29,000 \\
21,500 \\
19,500\end{array}$ & Cutlassfish & $\begin{array}{l}\mathrm{A}_{1} \\
\mathrm{DTNB} \\
\mathrm{A}_{2}\end{array}$ & $\begin{array}{l}27,000 \\
19,000 \\
16,000\end{array}$ \\
\hline Skipjack & $\begin{array}{l}\mathrm{A}_{1} \\
\mathrm{~A}_{2} \\
\mathrm{DTNB}\end{array}$ & $\begin{array}{l}30,000 \\
22,500 \\
20,000\end{array}$ & Pufferfish & $\begin{array}{l}\mathrm{A}_{1} \\
\mathrm{DTNB} \\
\mathrm{A}_{2}\end{array}$ & $\begin{array}{l}28,000 \\
19,000 \\
16,000\end{array}$ \\
\hline Bigeye tuna & $\begin{array}{l}\mathrm{A}_{1} \\
\mathrm{~A}_{2} \\
\text { DTNB }\end{array}$ & $\begin{array}{l}27,500 \\
21,000 \\
19,000\end{array}$ & Grunt & $\begin{array}{l}\mathrm{A}_{1} \\
\mathrm{DTNB} \\
\mathrm{A}_{2}\end{array}$ & $\begin{array}{l}28,500 \\
19,500 \\
16,000\end{array}$ \\
\hline Round herring & $\begin{array}{l}\mathrm{A}_{1} \\
\mathrm{~A}_{2}, \mathrm{DTNB}\end{array}$ & $\begin{array}{l}28,500 \\
21,000\end{array}$ & Filefish & $\begin{array}{l}\mathrm{A}_{1} \\
\mathrm{DTNB} \\
\mathrm{A}_{2}\end{array}$ & $\begin{array}{l}28,000 \\
19,000 \\
16,500\end{array}$ \\
\hline Sardine & $\begin{array}{l}\mathrm{A}_{1} \\
\mathrm{~A}_{2}, \mathrm{DTNB}\end{array}$ & $\begin{array}{l}28,000 \\
21,000\end{array}$ & Carp & $\begin{array}{l}\mathrm{A}_{1} \\
\mathrm{DTNB} \\
\mathrm{A}_{2}\end{array}$ & $\begin{array}{l}27,500 \\
18,000 \\
16,500\end{array}$ \\
\hline Bigeye scad & $\begin{array}{l}\mathrm{A}_{1} \\
\mathrm{~A}_{2}, \mathrm{DTNB}\end{array}$ & $\begin{array}{l}28,000 \\
20,000\end{array}$ & Requiem shark & $\begin{array}{l}\mathrm{A}_{1} \\
\mathrm{DTNB} \\
\mathrm{A}_{2}\end{array}$ & $\begin{array}{l}25,500 \\
17,500 \\
13,500\end{array}$ \\
\hline Horse mackerel & $\begin{array}{l}\mathrm{A}_{1} \\
\mathrm{~A}_{2}, \mathrm{DTNB}\end{array}$ & $\begin{array}{l}26,000 \\
18,000\end{array}$ & 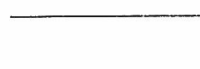 & & \\
\hline Threadfish & $\begin{array}{l}\mathrm{A}_{1} \\
\mathrm{DTNB} \\
\mathrm{A}_{2}\end{array}$ & $\begin{array}{l}26,000 \\
18,000 \\
15,000\end{array}$ & Rabbit & $\begin{array}{l}\mathrm{A}_{1} \\
\text { DTNB } \\
\mathrm{A}_{2}\end{array}$ & $\begin{array}{l}25,000 \\
18,500 \\
14,000\end{array}$ \\
\hline
\end{tabular}


Table 2. Light chain compositions of piscine ordinary muscle myosins

\begin{tabular}{lcccc}
\hline & \multicolumn{3}{c}{ Moles/mole of myosin } & \\
\cline { 2 - 4 } & DTNB & $\mathrm{A}_{1}$ & $\mathrm{~A}_{2}$ & \\
\hline Mackerel & 2.4 & 0.5 & 1.1 & 0.4 \\
Skipjack & 2.2 & 0.6 & 1.2 & 0.5 \\
Bigeye tuna & 2.4 & 0.9 & 0.7 & 1.3 \\
Threadfish & 2.5 & 0.6 & 0.9 & 0.6 \\
Cutlassfish & 1.9 & 0.6 & 1.5 & 0.4 \\
Grunt & 2.0 & 0.1 & 1.9 & 0.1 \\
Pufferfish & 2.2 & 0.6 & 1.2 & 0.5 \\
Filefish & 2.4 & 0.7 & 0.9 & 0.8 \\
Carp & 2.3 & 0.8 & 0.9 & 0.9 \\
Requiem shark & 2.2 & 1.3 & 0.5 & 2.6 \\
\cline { 1 - 4 } Rabbit & 2.0 & 1.4 & 0.6 & 2.3 \\
\hline
\end{tabular}

muscle myosin. ${ }^{20,40,41)}$ The remaining two moles were accounted for by $A_{1}$ and $A_{2}$. However, their relative ratios in myosin molecule fiuctuated very widely among the fishes tested. The molar ratios of $\mathbf{A}_{1}$ and $\mathbf{A}_{2}$ were in the range from 0.1 (grunt) to 2.6 (requiem shark). It seems interesting from the viewpoint of comparative biochemistry that the light chains of requiem shark and rabbit myosins resembled each other not only in their molecular weights but also in their molar ratios. Further studies will be needed to elucidate possible correlations between the piscine myosin light chain pattern and the degree of evolution.

Isolation and further characterization of myosin light chains from several fishes are now in progress.

\section{Acknowledgements}

The authors express their gratitude to Dr. Y. HIrosaki and Mr. K. SezAKI, the Enoshima Aquarium for a kind help in supplying requiem shark. This work was partly supported by a Grant-in-Aid from the Ministry of Education, Science and Cuiture.

\section{References}

1) L. C. Gershman, A. Stracher, and P. Dreizen: J. Biol. Chem., 244, 2726-2736 (1969).

2) J. Gazith, S. Himmelfarb, and W. F. HarringTON: J. Biol. Chem, 245, 15-22 (1970).

3) K. YAGI, Y. OKamoto, and Y. YaZAWA: $J$. Biochem., 77, 333-342 (1975).

4) S. Lowey and D. Rissy: Nature, 234, 81-85 (1971).

5) E. Gaetuens, K. Bárány, G. Bailin, H. OPPENHEIMER, and M. BÁRÁNY: Arch. Biochem.
Biophys., 123, 82-96 (1968).

6) A. G. WeEdS and H. Baker: Fed. Proc., 27, 391 (1968).

7) B. Z. Horváth and E. Gaetjens: Biochim. Biophys. Acta, 263, 779-793 (1972).

8) G. Matsuda, Y. Suzuyama, T. Maita, and T. UMEGANE: FEBS Lett., 84, 53-56 (1977).

9) A. Giambalvo and P. Dreizen: Biochim. Biophys. Acta, 537, 466-473 (1978).

10) I. SYrov́y: Int. J. Biochem., 10, 223-227 (1979).

11) A. G. WeEds: Nature, 223, 1362-1364 (1969).

12) A. G. Weeds and S. Lowey: J. Mol. Biol,, 61, 701-725 (1971).

13) D. R. Kominz, W.R. Carroll, E. N. SMith, and E. R. Mitchell: Arch. Biochem. Biophys., 79, 191-199 (1959).

14) A. G. Weeds and B. Pope: J. Mol. Biol., 111, 129-132 (1977).

15) G. Frank and A. G..Weeds: Eur. J. Biochem., 44, 317-334 (1974).

16) J. J. Connell: Biochem. J, 70, 81-91 (1958).

17) J. J. Connell and P.F. Howgate: Biochem. $J ., 71,83-86(1959)$.

18) G. HamoIR, H. A. MCKeNZIE, and M. B. SMITH: Biochim. Biophys. Acta, 40, 141-149 (1960).

19) H. Butrkus: J. Fish. Res, Bd. Canada, 23, 563573 (1966).

20) H. Butrkus: J. Fish. Res. Bd. Canada, 24, 1609 1612 (1967).

21) C. S. Chung, E. G. Richards, and H. S. Olcott: Biochemistry, 6, 3154-3161 (1967).

22) I. Syrony, A. Gaspar-Godfroid, and G. HAMOIR: Arch. Int. Physiol. Biochim., 78, 919 934 (1970).

23) R. Takashi, T. Murozuka, and K. Arai: Bull. Japan. Soc. Sci. Fish., 40, 1155-1161 (1974).

24) S. WataBe and K. Hashimoto: J. Biochem., 87, 1491-1499 (1980).

25) J. J. CONNEll: Biochem. J., 75, 530-538 (1960).

26) J. J. CONnell: Biochem. J., 80, 503-509 (1961).

27) R. TAKAShI: Bull. Japan. Soc. Sci. Fish., 39, 197-205 (1973).

28) T. MurozuKa and K. Aral: Bull. Japan. Soc. Sci. Fish., 42, 65-70 (1976).

29) R. Takashi, T. Murozuka, and K. Arai: Bull. Japan. Soc. Sci. Fish., 40, $1063-1069$ (1974).

30) N. SfkI: Bull. Japan. Soc. Sci. Fish., 42, 1169 1176 (1976).

31) B. Focant, F. Huriaux, and I. A. Johnston: Int. J. Biochem., 7, 129-133 (1976).

32) A. Perzanowska: Comp. Biochem. Physiol, 56B, 245-248 (1977).

33) B. Focant and F. Huriaux: FEBS Lett., 65, 16-19 (1976).

34) F. Huriaux and B. Focant: Arch, Int. Physiol. Biochim., 85, 917-929 (1977).

35) A. Perzanowska, Ch. Gerday, and B. Focant: Comp. Biochem. Physiol., 60B, 295-301 (1978).

36) W. F. StafFord III, E. M. SzentKkiralyi, and 
A. G. Szent-Györgyi： Biochemistry, 18, 5273- 39) W. T. Perrie and S. V. Perry： Biochem. J., 119, 5280 (1979).

31-38 (1970).

37) S. Lowey and J. C. Holt: Cold Spring Harbor 40) S. SARKAR: Cold Spring Harbor Symp. Quant. Symp. Quant. Biol., 37, 19-28 (1972). Biol., 37, 14-17 (1972).

38) K. Weber and M. Osborn: J. Biol. Chem., 244, 41) A. G. Weeds, R. Hall, and N. C. S. Surpway: 4406-4412 (1969). FEBS Lett., 49, 320-324 (1975). 